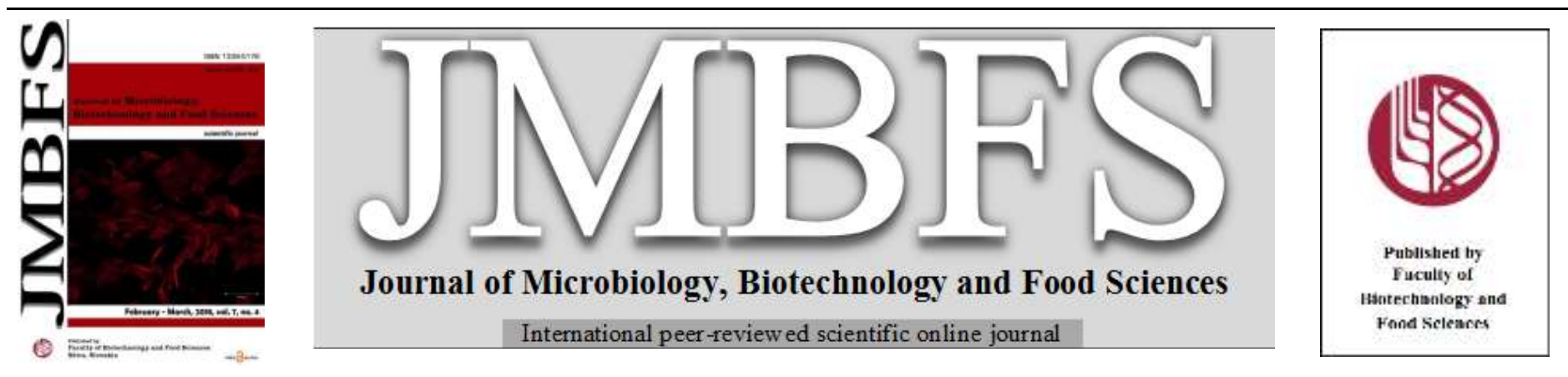

\title{
IN VITRO ANTISCHISTOSOMAL ACTIVITY OF ALLIUM CEPA L. (RED ONION) EXTRACTS AND IDENTIFICATION OF THE ESSENTIAL OIL COMPOSITION BY GC-MS
}

\author{
Ezzat Abdel-Lateef ${ }^{2}$, Ibrahim Rabia ${ }^{2}$, Mahfouz Abdel-Gawad ${ }^{1}$, Mortada El-Sayed ${ }^{l}$ \\ $\operatorname{Address}(e s)$ : \\ ${ }^{1}$ Theodor Bilharz Research Institute, Medicinal Chemistry laboratory, Korniash El-Nile, 12661Warrak El-Hadar, Giza, Egypt, Phone number:+20235403516. \\ ${ }^{2}$ Theodor Bilharz Research Institute, Parasitology Laboratory, Korniash El-Nile, 12661Warrak El-Hadar, Giza, Egypt.
}

*Corresponding author: ezzat_ea@yahoo.com

doi: 10.15414/jmbfs.2018.7.4.421-425

\section{ARTICLE INFO}

Received 15.9. 2017

Revised 17. 11. 2017

Accepted 2. 12. 2017

Published 1. 2. 2018

Regular article

orten 2 actess

\begin{abstract}
Allium cepa L. (red onion) is one of the most famous vegetable crops grown in Egypt due to its medical and nutritional importance. In vitro antischistosomal bioassay of ethyl acetate (EtOAc) and butanolic $(\mathrm{BuOH})$ fractions derived from methanolic $(\mathrm{MeOH})$ extract of A. cepa as well as the essential oil of plant bulbs was carried out using ascending doses. The chemical constituents of essential oil were further investigated using GC-MS analysis. The results revealed that the $\mathrm{MeOH}$ extract, EtOAc fraction, $\mathrm{BuOH}$ fraction and essential oil have a significant effect on adult Schistosoma mansoni worms. The essential oil of A. cepa gave high worm mortality (\%) at the concentration $500 \mu \mathrm{g} / \mathrm{mL}(75 \%), 250 \mu \mathrm{g} / \mathrm{mL}(50 \%)$ and $125 \mu \mathrm{g} / \mathrm{mL}(30 \%)$ death rate after 24 hours. GC-MS analysis of A. cepa essential oil exhibited different chemical volatile constituents such as organosulfur compounds, alcohols, acids, esters, furans, phenols, and aldehyde. 3, 5-Diethyl -1, 2, 4-trithiolane (10.17\%), 1, 3, 5-trithiolane (7.80\%), and 3-(2H-furanone, 2-hexyl-5-methyl) $(7.74 \%)$ represented the highest contents percent in essential oil of $A$. cepa bulbs.
\end{abstract}

In conclusion, the bulbs of A. cepa exhibited antischistosomal activities and contain a variety of bioactive chemical constituents and can be considered as a natural antischistosomal agent.

Keywords: Allium cepa L., antischistosomal activity, GC-MS analysis

\section{INTRODUCTION}

Schistosomiasis or bilharzia is one of the most widespread parasitic diseases in the world that has been neglected by governments (Mafud et al., 2016). Schistosomiasis is a tropical disease spread in more poverty and poor living conditions areas (WHO, 2010). The World Health Organization (WHO) estimated that in the year 2015; approximately 240 million peoples around the world were infected and the mortality rate of people is 280000 annually (Stein $\boldsymbol{e}$ al., 2015). Praziquantel (PZQ) is considered the drug of choice for schistosomiasis treatment (Hotez, 2009, Mantovani et al., 2013). Although it has been documented that PZQ has least side effects, the control of S.mansoni using PZQ at a population level faces some limitations (Metwalley, 2015). Therefore, the scientific community are contineously searching for some alternative drugs by screening botanical and chemical compounds for their potential activity as antischistosomal agents. Many reports exhibited that the medicinal plants are seems to be the new sources of antischistosomal drugs (Aline et al., 2013).

Allium (family Liliaceae) is the largest genus and the most important one in this family that include approximately 700 species. Allium genus is widely distributed in North Africa, Europe, Asia and America (El-Wakil et al., 2015). A cepa $\mathrm{L}$. (red onion) is a vegetable plant which possesses a strong aromas and flavors and has made it as important food ingredients. Red onion bulbs and essential oil are important parts widely used in food processing (Najjaa $\boldsymbol{e t}$ al., 2007; Che Othman et al., 2011). The bulbs of onion extracts were demonstrated several biological activities, such as antibacterial, antimutagenic, antitumor and antioxidants (Ismail et al., 2013; Ye et al., 2013; Abdel-Gawad et al., 2014a).

The main purpose of this study is to evaluate the in vitro antischistosomal activity of essential oil, $\mathrm{MeOH}$ extract of A. cepa bulbs and its derived fractions. Also, investigation of the chemical constituents of A. cepa essential oil by GC-MS analysis.

\section{MATERIAL AND METHODS}

\section{Plant materials}

The fresh bulbs of A. cepa (red onion) were purchased from local market, Giza Egypt in May 2015. The plant bulbs were kindly identified by Prof. Dr. Waffa Amer, Professor of plant taxonomy, Faculty of Science, Cairo University. The voucher sample was stored in Medicinal Chemistry Laboratory, Theodor Bilharz Research Institute. The fresh bulbs were cut into small piecies, milled with the electric mill and divided into parts. The first part was and kept for extraction of essential oil by hydrodistillation method and the other part was submitted to the extraction process.

\section{Extraction and fractionation processes}

One kilogram of freshly milled bulbs of A. cepa was extracted with $\mathrm{MeOH}$. The methanolic extract was evaporated under vacuum to dryness using rotatory evaporator. The dried methanolic extract was defatted using petroleum ether then the defatted $\mathrm{MeOH}$ extract was successively fractionated by partition using EtOAc and $\mathrm{BuOH}$. The two fractions were evaporated till dryness under reduced pressure. The dried extract and fractions were kept in dry vials for the antischistosomal test.

\section{Extraction of essential oil from A. cepa (red onion) bulbs}

Fresh bulbs ( $2.5 \mathrm{~kg}$ ) of A. cepa were submitted to hydrodistillation process using a Clevenger-type apparatus. The plant sample was immersed in distilled water $(2.5 \mathrm{~L})$ in round flask. The extraction step was executed for $7 \mathrm{~h}$ until complete plant exhaustion. The distillation process was started after $40 \mathrm{~min}$ of heating. The condensation of oil drops was obtained with continuous chilled water $\left(10^{\circ} \mathrm{C}\right)$. The experiments were repeated three successive times. The resulted essential oils were kept in tightly closed vials and preserved at $4{ }^{\circ} \mathrm{C}$ in a refrigerator to evaluate its antischistosomal activity and characterize of its chemical composition by GCMS

\section{In vitro antischistosomal bioassay screening}

Schistosoma mansoni worms were colected from the Schistosoma Biological Supply Center (SBSC), Theodor Bilharz Research Institute (TBRI), Giza, Egypt. The antischistosomal assay was carried out using the method described by Metwalley, (2015). S. mansoni worms were washed several times in sterile RPMI-1640 media (Cutilab, São Paulo, Brazil) buffered to pH 7.5, with HEPES $20 \mathrm{mM}$ and completed with streptomycin $(100 \mathrm{mg} / \mathrm{mL}), 10 \%$ fetal calf serum (Gibco, UK) and penicillin $(100 \mathrm{U} / \mathrm{mL})$. In $35 \mathrm{~mm}$ diameter $(35 \times 10 \mathrm{~mm})$ 
polystyrene petri dish, 10 adult $S$. mansoni worms were cultured in $10 \mathrm{~mL}$ sterile RPMI-1640 media with descending concentrations of plant extracts and oil(500, 250 and $125 \mu \mathrm{g} / \mathrm{mL}$ ) then incubated in a humid $5 \% \mathrm{CO}_{2}$ shaking incubator (SSI10R Large Refrigerated Incubator Shaker, Germany) at $37{ }^{\circ} \mathrm{C}$ for $24 \mathrm{hrs}$. In parallel, the adult worms were inserted in cultured media (RPMI-1640) containing $10 \%$ DMSO as solvent control. Worms exhibited no signs of motility for one minute, in addition to those showing deformities such as twisting, blackening, contracting and shrinking were considered dead.The efficacy of plant extracts on Schistosoma worms (viability, mortality and shrinking) was recorded using a stereomicroscope at different time intervals (1 h, 3 and $24 \mathrm{hrs}$ ) of incubation.

\section{GC-MS analysis}

The essential oil of A. cepa was performed using GC-MS instrument (Agilent Technologies, Palo Alto, CA). $9 \mu \mathrm{L}$ of essential oil were diluted with $991 \mu \mathrm{L}$ of EtOAc for GC. $0.5 \mu \mathrm{L}$ of the sample solution were injected into the gas chromatograph model (6890N Network GC system) coupled with a mass spectrometer (MS) model 5973 Network Mass Selective Detector (Agilent Technologies). A capillary column HP-5MS with $0.25 \mathrm{~mm}$ internal diameter, $0.25 \mu \mathrm{m}$ film thickness, and $30 \mathrm{~m}$ length was used. Helium gas was used as a carrier at a flow rate of $1.2 \mathrm{~mL} / \mathrm{min}$ (linear velocity: $33 \mathrm{~cm} / \mathrm{s}$ ). The injected sample was subjected into a split-splitless injector (split ratio $50: 1$ ) at $250{ }^{\circ} \mathrm{C}$, the program of oven temperature was the following: $45{ }^{\circ} \mathrm{C}$ for $5 \mathrm{~min}$.; an increase of $7{ }^{\circ} \mathrm{C} / \mathrm{min}$. up to $100{ }^{\circ} \mathrm{C}$, held for 15 minutes, from $100{ }^{\circ} \mathrm{C}$ to $150{ }^{\circ} \mathrm{C}$ with an increment of $5{ }^{\circ} \mathrm{C}$ per minute, held for 20 minutes, from $150{ }^{\circ} \mathrm{C}$ to $200{ }^{\circ} \mathrm{C}$ with an increment of $15^{\circ} \mathrm{C}$ per minute, held for 5 minutes. The MSD transfer line was set at a temperature of $250{ }^{\circ} \mathrm{C}$; MSD temperature quadrupole was $150{ }^{\circ} \mathrm{C}$ and ionization temperature was $230{ }^{\circ} \mathrm{C}$. Mass spectra were acquired at energy $70 \mathrm{eV}$ and the scan acquisition was performed in the range between 35 and 300 $\mathrm{m} / \mathrm{z}$. The characterization process of the essential oil chemical composition was determined by matching their mass spectra with database of NIST 02 and WILEY 275 libraries.

\section{RESULTS AND DISCUSSION}

\section{In vitro antischistosomal activity}

Schistosomiasis is one of the most predominant parasitic infection diseases worldwide. The results in Table 1 exhibited that the essential oil of $A$. cepa bulbs showed high antischistosomal activity $(25 \%-75 \%)$ and shrinking rate $(50 \%$ $70 \%$ ) at concentration $500 \mu \mathrm{g} / \mathrm{mL}$ at time interval $1 \mathrm{hr}$ to $24 \mathrm{hrs}$ (Hassan et al., 2016). Also, $\mathrm{BuOH}$ fraction derived from $\mathrm{MeOH}$ extract showed more potent antischistosomal activity $(25 \%-50 \%)$ and the highest shrinking rate $(25 \%-75$
$\%$ ) at concentration $500 \mu \mathrm{g} / \mathrm{mL}$ at time interval $1 \mathrm{hr}$ to $24 \mathrm{hrs}$. Praziquantel (PZQ) exhibited the highest antischistosomal activity $(50 \%-100 \%)$ and high shrinking rate $(50 \%-100 \%)$ at concentration $125 \mu \mathrm{g} / \mathrm{mL}$ at $1 \mathrm{hr}$ to $24 \mathrm{hrs}$ time interval.

Although the use of PZQ is considered as a drug of choice for treatment of schistosomiasis, there are significant limitations associated with its use. The most important one is, there are strains drug-resistant of the parasite that unable to weakness the oxidative stress directly in the tissue, but only it can decrease the activity of host's antioxidant system (Benkeblia et al., 2005; Obonyo et al., 2015). Therefore the new studies are focused on the parasite antioxidant pathway; since the parasite is subjected to a high oxidative stress mainly because of host's immune response (Benkeblia et al., 2005; Muema et al., 2015). Also, red onion may be expected as a natural antischistosomal drug due to the reactive oxygen species contribute to a large variety of diseases including schistosomiasis (Rizk et al., 2006). Thus, the plant under investigation was selected on the basis of its antioxidant potential (Abdel-Gawad et al., 2014b).

This study is matched with other previous studies which showed that the extracts of the stem and root of Abrus precatorius have a high activity agains schistosomules (Molgaard et al., 2001). Another study was reported that Zingiber officinale has antischistosomal properties against S. Mansoni (Sanderson et al. 2002). Also, Allium sativum showed antischistosomal activity against S.mansoni (Mohamed et al., 2005).

\section{GC-MS analysis of the essential oil of $A$. cepa (red onion)}

According to the high antischistosomal activity of A. Cepa essential oil of, this oil was subjected to GC-MS analysis in order to identify the chemical composition of this oil and investigate the relationships between antischistosomal properties of this oil and its chemical composition. The tentative identification of these phytochemicals was done by comparing their mass spectra with the WILEY 275 and NIST 02 libraries. The investigation of essential oil of $A$. cepa led to characterized 50 chemical compounds representing about $96.75 \%$ of the total essential oil content including organosulfur compounds $(49.47 \%)$ and other chemical constituents such as alcohols, acids, esters, furans, phenols, and hydrocarbons represent $47.28 \%$ of total as shown in Figure 1 and Table 2. The major chemical components were identified as 3, 5-diethyl -1, 2, 4-trithiolane $(10.17 \%), 1,3,5$-trithiolane $(7.80 \%), 3$-(2H-furanone, 2-hexyl-5-methyl) (7.74 $\%)$, dodecane $(6.77 \%), 4$-dibutylaminobut-2-yn-1-ol $(5.94 \%), 3(2 \mathrm{H})$-furanone 5 -methyl-2-octyl $(5.27 \%)$. These results are in agreement with previous studies reported by Colina-Coca et al. (2013), Mnayer et al. (2014) and El-Wakil et al. (2015). This suggests that the in vitro antischistosomicidal activity of the essential oil of red onion may be attributed to the sulfur and phenolic compounds which have antioxidant properties and may exert important protective effects against oxidative stress that occur during $S$. mansoni infection.

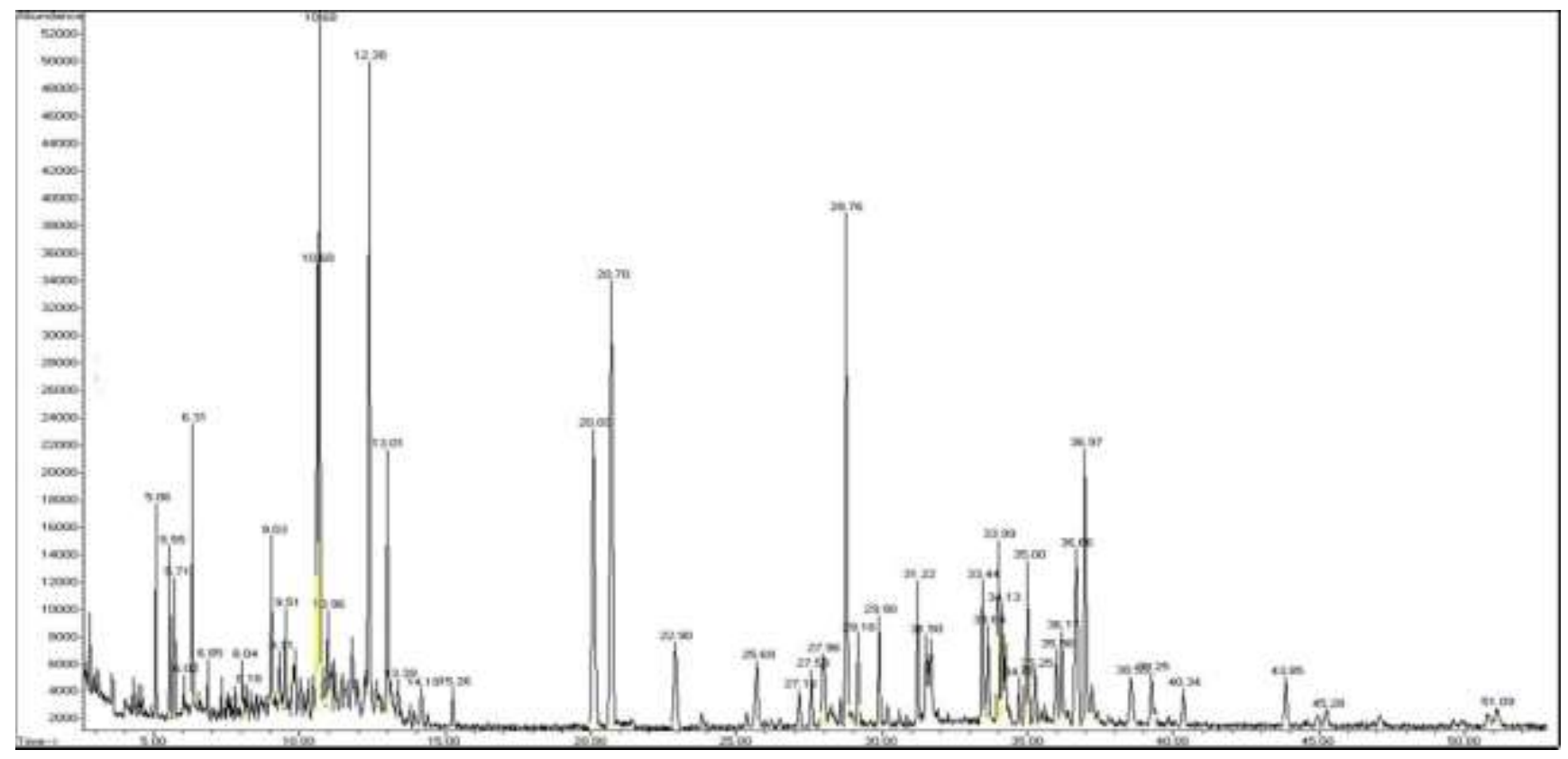

Figure 1 GC-MS chromatogram of the essential oil of A. cepa (red onion) bulbs. 
Table 1 Antischistosomal activity of A. cepa (red onion) essential oil, $\mathrm{MeOH}$ extracts EtOAc fraction and $\mathrm{BuOH}$ fraction

$$
\text { Mortality \% }
$$

Viability \%

Shrinking \%

\begin{tabular}{|c|c|c|c|c|c|c|c|c|c|c|c|c|c|c|c|c|c|c|c|c|c|c|c|c|c|c|c|}
\hline \multirow[t]{2}{*}{ Sample } & \multicolumn{3}{|c|}{$500 \mu \mathrm{g} / \mathrm{mL}$} & \multicolumn{3}{|c|}{$250 \mu \mathrm{g} / \mathrm{mL}$} & \multicolumn{3}{|c|}{$125 \mu \mathrm{g} / \mathrm{mL}$} & \multicolumn{3}{|c|}{$500 \mu \mathrm{g} / \mathrm{mL}$} & \multicolumn{3}{|c|}{$250 \mu \mathrm{g} / \mathrm{mL}$} & \multicolumn{3}{|c|}{$125 \mu \mathrm{g} / \mathrm{mL}$} & \multicolumn{3}{|c|}{$500 \mu \mathrm{g} / \mathrm{mL}$} & \multicolumn{3}{|c|}{$250 \mu \mathrm{g} / \mathrm{mL}$} & \multicolumn{3}{|c|}{$125 \mu \mathrm{g} / \mathrm{mL}$} \\
\hline & $\begin{array}{c}1 \\
h r\end{array}$ & $\begin{array}{c}3 \\
h r s\end{array}$ & $\begin{array}{l}24 \\
h r s\end{array}$ & $\begin{array}{c}1 \\
h r\end{array}$ & $\begin{array}{c}3 \\
h r s\end{array}$ & $\begin{array}{c}24 \\
h r s\end{array}$ & $1 \mathrm{hr}$ & $\begin{array}{c}3 \\
h r s\end{array}$ & $\begin{array}{c}24 \\
h r s\end{array}$ & $\begin{array}{c}1 \\
h r\end{array}$ & $\begin{array}{c}3 \\
h r s\end{array}$ & $\begin{array}{c}24 \\
h r s\end{array}$ & $\begin{array}{c}1 \\
h r\end{array}$ & $\begin{array}{c}3 \\
h r s\end{array}$ & $\begin{array}{c}24 \\
h r s\end{array}$ & $\begin{array}{c}1 \\
h r\end{array}$ & $\begin{array}{c}3 \\
h r s\end{array}$ & $\begin{array}{l}24 \\
h r s\end{array}$ & $\begin{array}{c}1 \\
h r\end{array}$ & $\begin{array}{c}3 \\
h r s\end{array}$ & $\begin{array}{c}24 \\
h r s\end{array}$ & $\begin{array}{c}1 \\
h r\end{array}$ & $\begin{array}{c}3 \\
h r s\end{array}$ & $\begin{array}{c}24 \\
h r s\end{array}$ & $1 \mathrm{hr}$ & $\begin{array}{c}3 \\
h r s\end{array}$ & $\begin{array}{c}24 \\
h r s\end{array}$ \\
\hline $\begin{array}{l}\text { Essential } \\
\text { Oil }\end{array}$ & 25 & 50 & 75 & 0 & 40 & 50 & 0 & 25 & 30 & 75 & 50 & 25 & 100 & 60 & 50 & 100 & 100 & 50 & 50 & 50 & 70 & 0 & 20 & 40 & 0 & 0 & 40 \\
\hline $\begin{array}{l}\text { MeOH } \\
\text { extract }\end{array}$ & 0 & 25 & 50 & 0 & 0 & 25 & 0 & 0 & 25 & 100 & 75 & 50 & 100 & 100 & 75 & 100 & 100 & 75 & 0 & 35 & 50 & 0 & 0 & 25 & 0 & 0 & 25 \\
\hline $\begin{array}{l}\text { EtOAc } \\
\text { fraction }\end{array}$ & 0 & 25 & 50 & 0 & 0 & 25 & 0 & 0 & 25 & 100 & 75 & 50 & 100 & 100 & 75 & 100 & 100 & 75 & 0 & 35 & 50 & 0 & 0 & 25 & 0 & 0 & 25 \\
\hline $\begin{array}{l}\text { BuOH } \\
\text { fraction }\end{array}$ & 25 & 25 & 50 & 0 & 25 & 50 & 0 & 0 & 50 & 75 & 75 & 50 & 100 & 75 & 50 & 100 & 100 & 50 & 25 & 50 & 75 & 0 & 25 & 50 & 0 & 0 & 50 \\
\hline PZQ & 75 & 100 & 100 & 75 & 100 & 100 & 50 & 75 & 100 & 25 & 0 & 0 & 25 & 0 & 0 & 50 & 25 & 0 & 75 & 100 & 100 & 75 & 100 & 100 & 50 & 75 & 100 \\
\hline
\end{tabular}

Negative control showed $0 \%$ mortality, $100 \%$ viability and $0 \%$ shrinking 
Table 2 Chemical composition of the essential oil of A. cepa (red onion) blubs.

\begin{tabular}{|c|c|c|c|c|c|}
\hline Peak no & $t_{R}$ & $\begin{array}{l}\% \text { of } \\
\text { total }\end{array}$ & MF & MW & Name \\
\hline 1 & 4.28 & 0.23 & $\mathrm{C}_{6} \mathrm{H}_{14} \mathrm{~S}_{2}$ & 150 & Dipropyl- disulfide \\
\hline 2 & 4.38 & 0.07 & $\mathrm{C}_{3} \mathrm{H}_{6} \mathrm{~N}_{4} \mathrm{O}_{2}$ & 130 & 3,3-bis(carbamino)diaziridine \\
\hline 3 & 4.47 & 0.14 & $\mathrm{C}_{6} \mathrm{H}_{8} \mathrm{~S}$ & 112 & 2,5-dimethyl- thiophene \\
\hline 4 & 4.93 & 0.11 & $\mathrm{C}_{9} \mathrm{H}_{21} \mathrm{NO}_{2}$ & 175 & $\mathrm{~N}, \mathrm{~N}$-dimethylformamide-dipropylacetal \\
\hline 5 & 5.06 & 1.40 & $\mathrm{C}_{6} \mathrm{H}_{8} \mathrm{~S}$ & 112 & 3,4-dimethyl-thiophene \\
\hline 6 & 5.55 & 1.43 & $\mathrm{C}_{4} \mathrm{H}_{10} \mathrm{~S}_{2}$ & 122 & Disulfide- methyl -propyl \\
\hline 7 & 5.71 & 1.10 & $\mathrm{C}_{4} \mathrm{H}_{8} \mathrm{~S}_{2}$ & 120 & Disulfide- methyl-1- propenyl \\
\hline 8 & 6.02 & 0.23 & $\mathrm{C}_{15} \mathrm{H}_{32} \mathrm{O}$ & 228 & 3,7,11-trimethyl-3- dodecanol \\
\hline 9 & 6.31 & 2.15 & $\mathrm{C}_{2} \mathrm{H}_{6} \mathrm{~S}_{3}$ & 126 & Dimethyl- trisulfide \\
\hline 10 & 6.54 & 0.11 & $\mathrm{C}_{10} \mathrm{H}_{20}$ & 140 & 1-methyl-2-propyl- cyclohexan \\
\hline 11 & 6.85 & 0.28 & $\mathrm{C}_{10} \mathrm{H}_{22}$ & 142 & Decane \\
\hline 12 & 7.31 & 0.29 & $\mathrm{C}_{11} \mathrm{H}_{24}$ & 156 & Decane-4-methyl \\
\hline 13 & 9.02 & 1.14 & $\mathrm{C}_{11} \mathrm{H}_{24}$ & 156 & Undecane \\
\hline 14 & 9.30 & 0.89 & $\mathrm{C}_{4} \mathrm{H}_{5} \mathrm{ClN}_{2} \mathrm{~S}$ & 148 & 2-ethyl-5-chloro-1,3,4-triazole \\
\hline 15 & 9.51 & 1.06 & $\mathrm{C}_{9} \mathrm{H}_{6} \mathrm{~F}_{3} \mathrm{NO}_{2}$ & 217 & 4,4,4-trifloro-1-(3-pyridinyl)- 1,3-butadienone \\
\hline 16 & 10.60 & 5.94 & $\mathrm{C}_{12} \mathrm{H}_{23} \mathrm{NO}$ & 197 & 4-dibutylaminobut-2-yn-1-ol \\
\hline 17 & 10.68 & 7.80 & $\mathrm{C}_{3} \mathrm{H}_{6} \mathrm{~S}_{3}$ & 138 & 1,3,5-trithiolane \\
\hline 18 & 10.96 & 0.84 & $\mathrm{C}_{17} \mathrm{H}_{37}$ & 240 & 2,6,10-trimethyl -tetradecane \\
\hline 19 & 11.80 & 0.67 & $\mathrm{C}_{20} \mathrm{H}_{40} \mathrm{O}$ & 296 & 1-ethenyloxy-octadecane \\
\hline 20 & 12.38 & 6.77 & $\mathrm{C}_{12} \mathrm{H}_{26}$ & 170 & Dodecane \\
\hline 21 & 13.00 & 2.97 & $\mathrm{C}_{13} \mathrm{H}_{28}$ & 184 & 2,6-dimethyl-undecane \\
\hline 22 & 13.13 & 0.48 & $\mathrm{C}_{2} \mathrm{H}_{6} \mathrm{~S}_{4}$ & 158 & Dimethyl -tetrasulfide \\
\hline 23 & 13.38 & 0.40 & $\mathrm{C}_{14} \mathrm{H}_{30} \mathrm{O}$ & 214 & 2-hexyl-octanol \\
\hline 24 & 14.16 & 0.72 & $\mathrm{C}_{5} \mathrm{H}_{10} \mathrm{~S}_{3}$ & 166 & 4,6-dimethyl-1,2,3-trithiolane \\
\hline 25 & 15.25 & 0.84 & $\mathrm{C}_{5} \mathrm{H}_{12} \mathrm{~S}_{2}$ & 136 & 2,2-bis(methylthiol)-propane \\
\hline 26 & 20.72 & 10.17 & $\mathrm{C}_{6} \mathrm{H}_{12} \mathrm{~S}_{3}$ & 180 & 3,5diethyl -1,2,4-trithiolane \\
\hline 27 & 25.71 & 2.96 & $\mathrm{C}_{6} \mathrm{H}_{3} \mathrm{ClN}_{2} \mathrm{OS}$ & 186 & 4-chloro-benzo(1,2,5trithiazol-5ol) \\
\hline 28 & 26.19 & 0.32 & $\mathrm{C}_{16} \mathrm{H}_{34} \mathrm{O}$ & 242 & 2-hexadecanol \\
\hline 29 & 27.57 & 1.14 & $\mathrm{C}_{5} \mathrm{H}_{12} \mathrm{~S}_{2}$ & 136 & 2,2-bis(methyl thio)-propane \\
\hline 30 & 27.95 & 2.93 & $\mathrm{C}_{6} \mathrm{H}_{11} \mathrm{NO}_{2} \mathrm{~S}$ & 161 & 1-nitro-2(2-propenyl thio)-propane \\
\hline 31 & 28.57 & 0.40 & $\mathrm{C}_{6} \mathrm{H}_{8} \mathrm{~S}$ & 112 & 2,4-dimethyl-thiophene \\
\hline 32 & 28.76 & 7.74 & $\mathrm{C}_{11} \mathrm{H}_{18} \mathrm{O}_{2}$ & 183 & 3(2H-furanone,2-hexyl-5-methyl) \\
\hline 33 & 29.89 & 2.45 & $\mathrm{C}_{8} \mathrm{H}_{18} \mathrm{~S}_{3}$ & 210 & 1,1-thiobis(3-methylthiol)- propane \\
\hline 34 & 31.21 & 1.87 & $\mathrm{C}_{13} \mathrm{H}_{26} \mathrm{O}$ & 198 & 2-tridecanone \\
\hline 35 & 32.58 & 0.61 & $\mathrm{C}_{3} \mathrm{H}_{6} \mathrm{O}_{2} \mathrm{~S}_{2}$ & 138 & 1,1dioxide -1,2-dithiolane \\
\hline 36 & 33.43 & 2.83 & $\mathrm{C}_{12} \mathrm{H}_{23} \mathrm{NO}_{2}$ & 213 & $\mathrm{~N},(1-C y c l o h e x y l r t h y l)-2-m e t h o x y-$ propanamide \\
\hline 37 & 33.64 & 1.50 & $\mathrm{C}_{12} \mathrm{H}_{26} \mathrm{O}_{2}$ & 202 & 4,5-decanediol-6-ethyl \\
\hline 38 & 33.99 & 3.06 & $\mathrm{C}_{6} \mathrm{H}_{12} \mathrm{~S}_{3}$ & 180 & 3,5-diethyl -1,2,4-tritholan \\
\hline 39 & 34.70 & 0.89 & $\mathrm{C}_{21} \mathrm{H}_{40} \mathrm{O}_{2}$ & 324 & Cyclohpetane carboxylic acid- pentadecyl ester \\
\hline 40 & 35.00 & 2.53 & $\mathrm{C}_{9} \mathrm{H}_{18} \mathrm{~S}_{3}$ & 222 & 2,2,4,4,6,6-hexamethyl -1,3,5-trithiolane \\
\hline 41 & 35.26 & 1.18 & $\mathrm{C}_{6} \mathrm{H}_{12} \mathrm{~S}_{3}$ & 180 & Trans-3,5-diethyl-1,2,4-trithiolane \\
\hline 42 & 35.99 & 1.56 & $\mathrm{C}_{8} \mathrm{H}_{11} \mathrm{NO}_{4} \mathrm{~S}_{2}$ & 249 & 3-(methylsulfonyl amino)-thiphene-2-carboxyli acid \\
\hline 43 & 36.17 & 2.02 & $\mathrm{C}_{6} \mathrm{H}_{13} \mathrm{ClOSi}$ & 164 & trans-2-chlorovinyl (cimethylethoxysilane) \\
\hline 44 & 36.96 & 5.27 & $\mathrm{C}_{13} \mathrm{H}_{22} \mathrm{O}_{2}$ & 210 & $3(2 \mathrm{H})$-furanone,5-methyl-2-octyl \\
\hline 45 & 37.21 & 0.83 & $\mathrm{C}_{10} \mathrm{H}_{18} \mathrm{OS}_{2}$ & 218 & 1,5-Dithiaspiro $(5,6)$ dodecan-7-ol \\
\hline 46 & 39.24 & 1.72 & $\mathrm{C}_{5} \mathrm{H}_{12} \mathrm{~S}_{2}$ & 136 & 2,2-bis(methylthiol) propane \\
\hline 47 & 43.85 & 2.32 & $\mathrm{C}_{8} \mathrm{H}_{16} \mathrm{O}_{2}$ & 144 & 2,2,4,6-tetramethyl-trans-1,3-dioxane \\
\hline 48 & 44.96 & 0.67 & $\mathrm{C}_{11} \mathrm{H}_{9} \mathrm{NO}_{2}$ & 187 & 2-quinolinecarboxylic acid, methyl ester \\
\hline 49 & 45.27 & 0.97 & $\mathrm{C}_{10} \mathrm{H}_{22} \mathrm{O}$ & 158 & 3-methyl,3-nonanol \\
\hline 50 & 50.80 & 0.75 & $\mathrm{C}_{6} \mathrm{H}_{12} \mathrm{~S}_{3}$ & 180 & 3,5-diethyl -1,2,4-trithiolane \\
\hline
\end{tabular}

$\left(t_{R}\right)$ Retention time, (MF) Molecular formula, (MW) Molecular weight.

\section{CONCLUSION}

The present study demonstrated that A. cepa essential oil and $\mathrm{BuOH}$ fraction showed antischistosomal activities in a time and dose-dependent manner. The higher antischistosomal activity of $A$. cepa essential oil was related to its chemical composition such as sulfur compounds, alcohols, acids, esters, and hydrocarbons. Therefore, it was suggested that $A$. серa may be used as a natura and safe therapeutic agent for human parasitic infectious diseases.
Acknowledgments: The authors are grateful to Theodor Bilharz Research Institute for supporting with necessary funds (Project No. $90 \mathrm{M}$ ).

\section{REFERENCES}

Abdel-Gawad, M.M., Abdel-Aziz, M.M., El-Sayed, M.M., El-Wakil, E.A., Abdel-Lateef, E.E. (2014b). In vitro antioxidant, total phenolic and flavonoid contents of six Allium species growing in Egypt. J. Microbiol. Biotech. Food Sci,3(4),343-346. 
Abdel-Gawad, M.M., Abdel-Aziz, M.M., El-Sayed, M.M., El-Wakil, E.A., Abdel-Lateef, E.E. (2014a). Chromatographic isolation of Allium cepa (ssp. red onion) and its cytotoxic activity against human liver carcinoma cell lines (HepG2). Int. J.Pharm. Pharma. Sci,6(8), 108-111.

Benkeblia N. (2005). Free-radical scavenging capacity and antioxidant properties of some selected onions (Allium cepa L.) and garlic (Allium sativum L.) extracts. Braz. Arch. Biol. Technol, 48(5), 753-759.http://dx.doi.org/10.1590/S151689132005000600011.

Castro, A.P., De Mattos, A.C.A., Souza, R.L.M., Marques, M.J., Dos Santos, M.H.(2013). Medicinal plants and their bioactive constituents: A review of bioactivity against Schistosoma mansoni. J. Med. Plants Re,.7(21),15151522.http://dx.doi.org/ 10.5897/JMPR12.0750.

Che Othman, S.F., Idid, S.Z., Koya, M.S., Rehan, A.M., Kamarudin,K.R.(2011) Antioxidant study of garlic and red onion: a comparative study. Pertanika $J$. Trop. Agric. Sci,34(2),253 -261.

Colina-Coca, C., Gonza'Lez-Pen, D., Vega, E., Deancos, B., Sa'Nchez-Moreno, C. (2013). Novel approach for the determination of volatile compounds in processed onion by headspace gas chromatography-mass spectrometry (HS GCMS). Talanta. 15(103),137-44.https://doi.org/10.1016/j.talanta.2012.10.022. El-Wakil, E.A., El-Sayed, M.M., Abdel-Lateef, E.E.(2015). GC-MS investigation of essential oil and antioxidant activity of Egyptian white onion (Allium cepa L.). Int. J. Pharm. Sci. Res,6(3),537-543.

Hassan, E.A., Abdel-Rahman, M.A., Ibrahim, M.M., Soliman, M.F.M. (2016). In vitro antischistosomal activity of venom from the Egyptian snake Cerastes

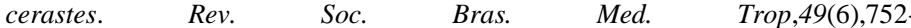
757.https://doi.org/10.1590/0037-8682-0241-2016.

Hotez, P.J.(2009). Mass drug administration and integrated control for the world's high-prevalence neglected tropical diseases. Clin. Pharmacol. Ther, 85(6),659-64.

Ismail, S., Jalilian, F.Z., Talebpour, A.H., Zargar, M., Shameli, K., Sekawi, Z., Jahanshiri,F. (2013). Chemical composition and antibacterial and cytotoxic activities of Allium hirtifolium Boiss. BioMed. Res. Int, 18.http://dx.doi.org/10.1155/2013/696835.

Mafud, A.C., Silva, M.P., Monteiro, D.C., Oliveira, M.F., Resende, J.G., Coelho, M.L., De Sousa, D.P., Mendonça, R.Z., Pinto, P.L., Freitas, R.M., Mascarenhas, Y.P., De Moraes, J. (2016). Structural parameters, molecular properties, and biological evaluation of some terpenes targeting Schistosoma mansoni parasite. Chem. Biol. Interact,25(244),129-39.https://doi.org/10.1016/j.cbi.2015.12.003

Mantovani, A.L.L., Vieira, G.P.G., Cunha, W.R., Groppo, M., Santos, R.A., Rodrigues, V., Magalhães, L.G. Corrti, A.E.M. (2013). Chemical composition, antischistosomal and cytotoxic effects of the essential oil of Lavandula angustifolia grown in Southeastern. Brazil. Rev. Bras. Farmacogn, 23(6), 877884.http://dx.doi.org/10.1590/S0102-695X2013000600004.

Metwalley K.M.(2015). Assessment of the antischistosomal activity of some plant extracts against Schistosoma mansoni infection. World J. Med. Sci,12(2),162-169.http://dx.doi.org/10.5829/idosi.wims.2015.12.2.93197. Mnayer, D., Fabiano-Tixier, A.S., Petitcolas, E., Hamieh, T., Nehme, N., Ferrant, C., Fernandez, X, Chemat, F.(2014). Chemical composition, antibacterial and antioxidant activities of six essentials oils from the Alliaceae family. Molecules, 19(12),20034-53.http://dx.doi.org/10.3390/molecules191220034.

Mohamed, A.M., Metwally, N.M., Mahmoud, S.S.(2005). Sativa seeds against Schistosoma mansoni different stages. Mem. Inst. Oswaldo Cruz, 100(2), $205-$ 211.http://dx.doi.org//S0074-02762005000200016.

Molgaard, P., Nielsen, S.B., Rasmussen, D.E., Drummond, R.B., Makaza, N., Andreassen, J. (2001). Anthelminitic screening of Zimbabwean plants traditionally used against schistosomiasis. J. Ethnopharmacol,74(3),257264.https://doi.org/10.1016/S0378-8741(00)00377-9.

Muema, J.M., Obonyo, M.A., Njeru, S.N., Mwatha, J.K.(2015).Antischistosomal effects of selected methanolic plant extracts in Swiss albino mice infected with Schistosoma mansoni. Europ. J $\quad$.Med. Plants,9(1),111.https://doi.org/10.9734/EJMP/2015/16953.

Najjaa, H., Neffati, M., Zouari, S., Ammar, E. (2007). CR Chimie, 10(9),820826.https://doi.org/10.1016/j.crci.2007.03.003.

Rizk, M., Fayed, T.A., Badawy, M., El-Regal, N.S.(2006). Effect of different durations of Schistosoma mansoni infection on the levels of some antioxidants in mice. Trend. Med.Res, 1,66-74.http://dx.doi.org/10.3923/tmr.2006.66.74.

Sanderson, L., Bartlett, A., Whitifield, P.J. (2002).In vitro and in vivo studies on the bioactivity of a ginger (Zingiber officinale) extract towards adult schistosomes and their egg production. J. Helminthol, 76(3),241247.https://doi.org/10.1079/JOH2002116.

Stein, E.M., Machado, L.P., Roffato, H.K., Miyasato, P.A., Nakano, E., Colepicolo, P., Anderguetti, D.X.(2015). Antischistosomal activity from Brazilian marine algae. Rev. Bras. Farmacogn,25(6),663667.http://dx.doi.org/10.1016/j.bjp.2015.09.005.

World Health Organization. WHO. Working to overcome the global impact of neglected tropical diseases - First WHO report on neglected tropical diseases. Geneva, Switzerland: WHO Press; 2010

Ye, C., Dai, D., Hu, W.(2013). Antimicrobial and antioxidant activities of the essential oil from onion (Allium cepa L.). Food Cont,30(1),48-

53.https://doi.org/10.1016/j.foodcont.2012.07.033. 